\title{
Sixty years of the National Food Program in Brazil
}

\section{Sessenta anos do programa nacional de alimentação escolar no Brasil}

\author{
Rosana Maria NOGUEIRA ${ }^{1}$ \\ Bruna BARONE ${ }^{1}$ \\ Thiara Teixeira de BARROS ${ }^{1}$ \\ Kátia Regina Leoni Silva Lima de Queiroz GUIMARÃES' \\ Nilo Sérgio Sabbião RODRIGUES ${ }^{1}$ \\ Jorge Herman BEHRENS ${ }^{1}$
}

School meals were introduced in the Brazilian political agenda by a group of scholars known as nutrition scientists' in the 1940s. In 1955, the Campanha de Merenda Escolar, the first official school food program, was stablished, and sixty years after its inception, school food in Brazil stands as a decentralised public policy, providing services to students enrolled in public schools, which involve the Brazilian federal government, twentyseven federative units, and their 5,570 municipalities. Throughout its history, school food has gone through many stages that reflect the social transformations in Brazil: from a campaign to implement school food focused on the problem of malnutrition and the ways to solve it, to the creation of a universal public policy relying on social participation and interface between other modern, democratic, and sustainable policies, establishing a strategy for promoting food and nutrition security, development, and social protection. In this article, the School Food Program is analyzed from the perspective of four basic structures that support it as public policy: the formal structure, consisting of legal milestones that regulated the program; substantive structure, referring to the public and private social actors involved; material structure, regarding the way in which Brazil sponsors the program; and finally, the symbolic structure, consisting of knowledge, values, interests, and rules that legitimatize the policy.

Keywords: School food. Public policies. Nutrition programs and policies.

RE S U M O

A alimentação escolar foi inserida na agenda pública brasileira por um grupo de intelectuais, os chamados cientistas da nutrição, nos anos 1940. Em 1955 foi decretado o início do Programa de Alimentação com a

\footnotetext{
1 Universidade Estadual de Campinas, Faculdade de Engenharia de Alimentos, Departamento de Alimentos e Nutrição. R. Monteiro Lobato, 80, Barão Geraldo, 13083-862, Campinas, SP, Brasil. Correspondência para/Correspondence to: JH BEHRENS E-mail: <behrens@fea.unicamp.br>.
} 
instituição da Campanha de Merenda Escolar, subordinada ao Ministério da Educação. Após sessenta anos de história, a alimentação escolar no Brasil se destaca como uma política pública descentralizada de atendimento aos estudantes matriculados na rede pública de ensino a qual envolve o governo federal brasileiro, as 27 entidades federativas e seus 5570 municípios. Ao longo de sua história, a alimentação escolar passou por várias etapas que refletem as transformações sociais do Brasil: partindo de uma campanha para a merenda escolar, focada no problema da desnutrição e nas formas de resolvê-la, passou para a criação de uma política pública universal contando com a participação social e interface entre outras políticas modernas, democráticas e sustentáveis, estabelecendo uma estratégia de promoção da segurança alimentar e nutricional, desenvolvimento e proteção social. Neste artigo, o Programa de Alimentação Escolar é analisado a partir de quatro estruturas básicas que o sustentam como política pública: a estrutura formal, composta pelos marcos legais que normatizam o programa; a substantiva, referente aos atores sociais públicos e privados envolvidos; a material que diz respeito à maneira como o Estado brasileiro financia o programa e, por fim, a estrutura simbólica composta pelos saberes, valores, interesses e regras que legitimam a politica.

Palavras-chave: Alimentação escolar. Políticas públicas. Programas políticas de nutrição e alimentação.

\section{INTRODUCTION}

The provision of school meals is part of the body of public policies that supplement education services. Hence, efficient learning requires healthy meals and proper learning environments, allowing for the development of socialization, communication, and nutrition education in students ${ }^{1}$.

One of the first known programs for education and nutrition combined dates back to around 1790, in present-day Germany. The provision of school meals in the United States followed much the same pattern as that of Europe, but it was not to be enforced for another 100 years (1890); it was sporadic in its character, and implemented by private societies and associations interested in the welfare and education of children².

Historically, school meals were introduced as part of an education policy, that is, as a political aid strategy for schools, aiming to attract students, avoid truancy, and improve school attainment and progression. It focused mainly on the working classes and the population of Brazil's least developed regions. In this context, the issues of famine and malnutrition were seen as impediments to school attendance ${ }^{3}$. Nevertheless, it was not until 1946 that a more robust proposal of an institutional project of school meals was put forward in Brazil by the United Nations Children's Fund (Unicef). By that time, Unicef's main objective was to help the development of aid programs benefitting non-European children ${ }^{4}$.

Only in 1955 the Ministry of Education and Culture launched its National School Lunch Program and instituted by decree ${ }^{5}$ the School Food Campaign. Later, with the intention of transforming the program into a broad national campaign, the name also changed in 1956 to National School Food Campaign. At that time, food and nutrition constituted themselves as a political practice and knowhow, and the National School Lunch Campaign was a key component of the food policy 4 .

Since 1970, foodstuffs were purchased from the domestic market, effectively introducing pre-prepared foods, which were more expensive, of low acceptability, and without nutritional additions compared with basic foodstuffs ${ }^{6}$.

But on other hand, such products helped the program's logistics, since they were pre-prepared and only needed to be rehydrated for consumption, thus facilitating their use. Nevertheless, only a few companies supplied this sort of product on a countrywide basis, which led to the formation of lobby groups that exerted pressure on the State ${ }^{5}$, since the acquisition of food products in order to implement the program was done in a centralized manner through the Ministry of Education Ministry of Education, and this, according to Paiva et al. ${ }^{7}$, affected the operational side and efficiency of the program. 
This business sector - pre-prepared food companies - definitely interfered with the course of the program as the nutritional technical process was neutral and disengaged from the social dimension of the program, emphasizing fortified foods. In addition to this, other factors allied to political and financial issues eventually influenced the school food policy6.

From 1972 to 1974, the I Programa Nacional de Alimentação e Nutrição (Pronan, I National Food and Nutrition Program) emerged, guided by the I Plano Nacional de Desenvolvimento (PND, I National Development Plan), and one of its guidelines was the use of traditional staples ${ }^{8}$.

But it was from 1975 to 1979 that the II Pronan was introduced, guided by the II PND, aiming to increase the focus given to nutrition programs on the modernization of production and marketing system of staples, and to encourage small farmers through supplementary food programs. This supplementary food for schoolchildren from 1976 was funded by the Ministry of Education and Culture and managed by the National School Food Campaign, becoming known in 1979 as the Programa Nacional de Alimentação Escolar (PNAE, National School Food Program) ${ }^{9}$.

In the 1980s a process of decentralization of Brazilian school meal provision took place, when federal funds destined for the acquisition of food products were transferred to the states and municipalities of the federation, since further investments on the infrastructure of schools, hiring of cooks, etc., became the responsibility of states and, in particular, municipalities ${ }^{1}$. Therefore, after decades of actions and public investments, the provision of school meals in Brazil became a policy of universal aid, formulated through routines and procedures, which defined the role of the Union, states, municipalities and social control through the Municipal Council of School Meals ${ }^{6}$.

In short nowadays school food in Brazil represents the advances in the last few decades, from a handout campaign for supplying meals to a universal public policy connected to other social, educational, economic development, and sustainability policies. As with any public policy, it requires a critical analysis of its implementation in an attempt to evaluate its strengths and weaknesses.

Public policies can be analyzed from various perspectives and each one captures a certain aspect as for example, the social actors, state and private investments, the related legislation, and the symbolic meaning ${ }^{10}$. So, this article aims to analyze the progression of school meal provision as one of the most enduring public policies in Brazil, and for this purpose the methodology proposed by Di Giovanni ${ }^{10}$ was used, which includes four elementary structures, namely formal, substantive, material, and symbolic structures. The proposed analysis points out theories, practices and results, social actors, interests and rules, financial support and management, and even the meaning expressed by values, knowledge, and languages behind the current national program of school meals.

\section{Programa Nacional de Alimentação Escolar}

At present, Brazil's Programa Nacional de Alimentação Escolar is the second largest in the world, serving approximately 50 million students daily, second only to India's, which provides meals to over 100 million students ${ }^{11}$. Its universality, as much as its continuity, were the principles which always guided the program. Nevertheless, such principles were difficult to meet, mainly due to external, political, academic, or even personal pressures throughout its history ${ }^{6}$. In Latin America, only Brazil and Uruguay count on universal programs, even though they differ as far as their administration is concerned ${ }^{12}$.

In Brazil the Programa Nacional de Alimentação Escolar is one of the oldest and longestlasting public policies, which has been in force uninterruptedly and overseen by the Ministry of 
Education ${ }^{11}$. It was forged as a fundamental students' right, since one of its principles is to guarantee the provision of meals on 200 school days to all students attending public federal, state, district, and municipal schools, nurseries, preschools, primary schools, secondary schools, schools for youths and adults, as well as students in charitable institutions, church, and community schools ${ }^{13}$. Chart 1 shows the main historical and legal landmarks in the provision of school meals in Brazil.

Currently, the main objectives of PNAE are to contribute to students' growth, biopsychosocial development, learning, academic attainment, and establishment of healthy eating habits through food and nutrition education, and to provide meals that cover their nutritional requirements during the school year; PNAE became an important strategy to improve food security by promoting the human right to appropriate nutrition ${ }^{16}$.

Public policies grow out of the confluence of social and political agendas when a demand from society - or from groups within society - is approached through State intervention, which then summarily creates specific laws and mechanisms for their fulfilment. Nevertheless, a closer look reveals that historical, political, economic, cultural and social factors lie beneath public policy-making. Their analysis allows us to understand its complex structure ${ }^{10}$. Therefore, Di Giovanni ${ }^{10}$ suggests an angle for analysis of public policies based on four elementary structures through which it is possible to gather the articulation of laws, material resources, actors,

Chart 1. Landmarks in the provision of school food in Brazil: 1955-2013.

\begin{tabular}{|c|c|}
\hline Year & Main events \\
\hline 1955 & Institution of the Campanha da Merenda Escolar. \\
\hline 1956 & Program reaches nationwide coverage. \\
\hline 1960 & Provision of full meals to students. \\
\hline 1970 & The Brazilian government takes on the running costs of the program. \\
\hline 1972 & I Pronan: introduced the use of traditional staples \\
\hline 1975 & $\begin{array}{l}\text { II Pronan: expansion of the focus given to nutrition programs on modernization of the system of production and marketing } \\
\text { of food commodities. }\end{array}$ \\
\hline 1979 & The PNAE is instituted. \\
\hline 1980 & A process of decentralization of Brazilian school meal provision took place at the PNAE. \\
\hline 1988 & Promulgation of the Federal Constitution, turning PNAE into a duty of the State. \\
\hline 1993 & Creation of the Fundação de Assistência ao Estudante: official decentralization of PNAE's management. \\
\hline 1994 & $\begin{array}{l}\text { Product acquisition made through voluntary transfers of financial resources. Studies to establish per capita values. Requirement } \\
\text { for setting up a Conselho de Alimentação Escolar at the federal level. }\end{array}$ \\
\hline 2001 & $\begin{array}{l}\text { Regulation establishes that at least seventy per cent of financial resources transferred by the FNDE must be directed exclusively } \\
\text { towards the acquisition of basic products, taking into account regional eating habits and the agricultural inclination of } \\
\text { municipalities, with a view to strengthening local economies. }\end{array}$ \\
\hline 2005 & Conselho Federal de Nutricionistas sets up the duties of dieticians in the context of PNAE. \\
\hline 2006 & $\begin{array}{l}\text { Interministerial ordinance establishes directives for the Promotion of Heathy Food in kindergartens, elementary, and high } \\
\text { schools, both in the public and private sectors. Establishment of the Sisan. }\end{array}$ \\
\hline 2009 & $\begin{array}{l}\text { Law } n^{\circ} 11.947 \text {, which sets up guidelines on school food. Establishment of links between PNAE and family farming and } \\
\text { creation of the Centro Colaborador de Alimentação e Nutrição Escolar by Resolution n } 38 \text {. }\end{array}$ \\
\hline 2013 & $\begin{array}{l}\text { Passing of a new resolution from FNDE, setting up guidelines on school meals given to elementary school children through } \\
\text { PNAE. Greater participation of family farming. }\end{array}$ \\
\hline
\end{tabular}

Note: Adapted: Nogueira ${ }^{6}$, Barone ${ }^{14}$, and Fundo Nacional de Desenvolvimento da Educação (FNDE) ${ }^{15}$.

PNAE: Programa Nacional de Alimentação Escolar; Sisan: Sistema Nacional de Segurança Alimentar e Nutricional; Pronan: Programa Nacional de Alimentação e Nutrição. 
and social values as an answer to a social demand which, in this instance, consists of the insertion of school meals in Brazilian public education.

Figure 1 presents the four basic structures from which this article analyzes the PNAE.

The formal structure is formed by theories, practices, history, and fundamental results, especially as far as laws that regulate a public policy are concerned. PNAE is set up by Federal Law $n^{\circ} 11.947 / 2009^{17}$ which regulates the provision of school meals, and it was altered by Law $n^{\circ} 12.982 / 2014^{18}$, which prescribes the appropriate provision of school meals to students who have specific health conditions. The operational aspects of PNAE are rather complex, due to the involvement of several sectors of government and civil society in the municipal, state, and federal arenas, and because it is necessary to have favorable conditions within those arenas for the operational aspects to work properly ${ }^{16}$.

International programs such as United States Agency for International Development's Food for Peace Program and the World Food Program of the United Nations exerted influence on the Brazilian school food policy during the 1950s and 1970s, characterized by the presence of food products acquired mainly from North American companies ${ }^{17}$. The 1980 s and 1990s were marked by the decentralization of public policies, including the provision of school meals, establishing state and municipal management of

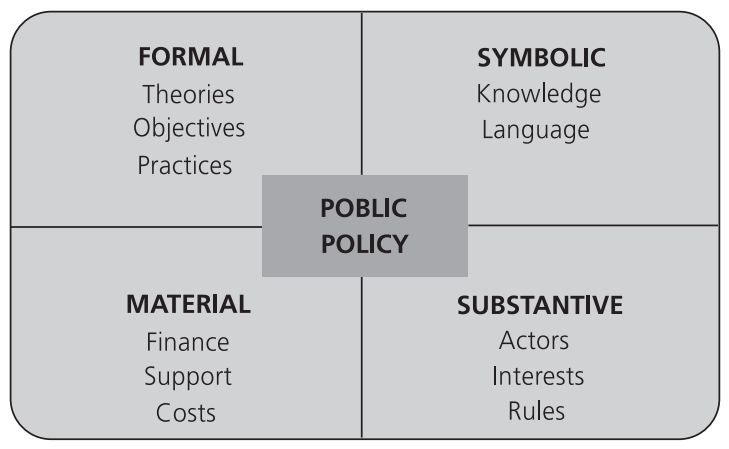

Figure 1. The four basic structures used for analyzing the Programa Nacional de Alimentação Escolar (PNAE), according to the perspective of Di Giovanni ${ }^{10}$. the program, which, up until then, had been completely centralized within the federal government, both in its formulation and implementation. Prior to that, food products were acquired in a centralized manner, through the Ministry of Education, which made their distribution to various municipalities across the country difficult, thus affecting their quality ${ }^{6}$.

Despite the beginning of the school food program in the 1950s, it was only with the Fome Zero strategy in 2003 that it emerged as a major national public policy. Since then there have been many advances in relation to the establishment of technical and operational criteria, aiming at greater flexibility, efficiency, and effectiveness in management, particularly with respect to the expansion and strengthening of social control and prescriptive strategies for the actions of dieticians as those who hold technical responsibilities in the program $^{19}$.

Continuing the implementation of the Fome Zero strategy, the Sistema Nacional de Segurança Alimentar e Nutricional (Sisan, National Food and Nutrition Security System, Organic Law on Food Security and Nutrition) aimed to formulate and implement policies and food and nutrition security plans to stimulate the integration of efforts between government and civil society and to promote monitoring, tracking, and evaluation of food and nutrition security in the country ${ }^{20}$. In this sense, PNAE and Programa de Aquisição de Alimentos (Food Acquisition Program) are both inserted in Sisan, ensuring the human right while fostering local agricultural development ${ }^{21,22}$.

Social actors, their interests, and rules make up the substantive structure of a public policy. Up until the point at which school meals reach Brazilian students - the reason behind real users of PNAE -, various social actors play different roles: on the one hand, State actors occupy public functions and mobilize the resources associated with such functions (e.g. politicians and civil servants who work within the bureaucracy) and, 
on the other, private actors from the civil society, such as students, members of civil society organizations and suppliers to the program. The Brazilian Ministry of Education, the main representative of the State, acts through the Fundo Nacional de Desenvolvimento da Educação (FNDE, National Education Development Fund) in the directly channeling of financial resources to 5,570 municipalities throughout the country. At the municipal level, it is the task of the secretary of education to manage the resources destined to schools meals. Secretaries are aided by a technical member of staff, who, according to current legislation, must hold a university degree in nutrition ${ }^{23}$.

Only from 2003 were dieticians included in the general coordination of the program at the federal level, in the FNDE, which highlights the fact that the technical responsibility of the school food program in the states, Federal District, municipalities, and federal schools falls under a dietician's responsibility ${ }^{19}$. According to Chaves et al. ${ }^{24}$, the percentage of Brazilian municipalities employing dieticians has risen from 12 to 79 per cent between 2003 and 2011.

In the private sector, the suppliers of food products for the program stand out. Their importance is paramount for the implementation of PNAE. In the mid-twentieth century, when school meals were first provided in Brazil, the process was a handout by its nature and school meals were made up mainly of products donated by the United States of America ${ }^{6}$. It was a convenient solution at that time, since the nutritional condition of the majority of school children in public schools was poor and lacking in nutritional supplementation ${ }^{12}$. Nevertheless, those products were difficult to prepare and store, besides being unacceptable and unfamiliar to the Brazilian palate, such as bulgur wheat (mashed, cooked and dried wheat grains, usually used in soups or meat dishes) and some soy-based combinations ${ }^{4}$. The national share with regard to the purchase of foodstuffs followed agreements with the North American government, which gave rise to the establishment of quotas of food products for this market.

Gradually, this profile of purchases of foodstuffs changed, and so did that of purchases within the home market, which led to the introduction of pricier pre-prepared food products of low popularity and no nutritional advantages when compared with other basic food products ${ }^{19}$.

Political issues and the severe economic crisis which affected Brazil between 1970 and 1990 influenced the school meals policy. Characteristic of this period was the centralization of purchases by the federal government and the strong presence of the processed food industry, which affected the objectives of the program ${ }^{6}$. Menu planning was still under the care of the Ministry of Education and food products were acquired through public tender and distributed nationwide ${ }^{25}$.

After the approval of the new federal constitution of 1988, which was considered to be a landmark in the Brazilian re-democratization process in its recognition of social rights, the provision of school meals became a duty of the State and a right of all students attending public schools $^{26}$. At the time, decentralization was the main feature of new social policies of redemocratization within different sectors, such as education, social care, health, sanitation, and housing ${ }^{27}$. There was an attempt to achieve greater social inclusion in the execution and supervision of PNAE, thus the need of state and municipal school food councils ${ }^{28}$.

The decentralization policy, as defined by the Ministry of Education, came to supplement the financing of the program. It became accountable to the Tribunal de Contas da União by the municipalities, which were responsible for its technical and financial management. The Tribunal de Contas da União is an administrative tribunal which arbitrates the accounts of public administrators and other personnel where goods and other federal public resources are concerned. It also deals with arbitrations of any person who may have caused loss or any irregularity which 
may have resulted in damages to the taxpayer. Due to the decentralization process, the Education State Offices started to advise those municipalities that required technical and administrative support to work with PNAE ${ }^{29}$.

In 2000 the School Food Council was set up as a deliberative, supervising, and advisory agency for PNAE, at both state and municipal levels, with a view to enforcing the communal participation on the program ${ }^{30}$.

Despite the importance of social control, it is a known fact that the mere setting up of such councils is no guarantee for the efficiency of their actions. According to Lüchmann ${ }^{31}$, it is important to focus on the factors which prevent processes of participation that involve questions of political, economic, social, and cultural natures and are connected to a society, which, structurally, is laid on the pillars of cronyism, authoritarianism, and social inequality, which is still the case in Brazil today.

Regular scheduling of meetings is an important factor. Research has pointed out the small number of School Food Councils that meet monthly in Brazilian municipalities. In the states of São Paulo and Santa Catarina, around $50^{32}$ and $26 \%{ }^{33}$ of municipalities, respectively, claim to meet regularly, and according to a nationwide survey, only an average of $31 \% \mathrm{do}^{34}$.

Santos et al. ${ }^{35}$ have identified lack of time as one of the main factors preventing the proper performance of the councils. Machado et al. ${ }^{36}$ has also asserted that a lack of time for social control activities and dearth of regulation in this respect were pointed out as barriers to the efficient performance of councilors.

Another important factor for the School Food Council to perform efficiently is linked to the lack of training of its members ${ }^{32}$. In the majority of cases, members are neither clear about the role of the School Food Council nor of their own roles as representatives of a certain segment. Auditing carried out by the Tribunal de Contas da
União has concluded that the performance of the School Food Council is damaged by the lack of technical knowledge of its councilors, which is reflected in a report sent to the FNDE ${ }^{37}$.

\section{Family farming and PNAE: A recent development}

Recently, an official program was created to facilitate the acquisition of food products from these farmers, through public tender and at competitive prices to those of regional markets. Its goal is to promote access to foodstuffs by disadvantaged populations and to promote social and economic inclusion in the countryside by strengthening family farming ${ }^{25}$. Through this program municipalities are also able to acquire food products without the need of public tender. If choosing this option, the acquisition is made through public calls for proposals ${ }^{38}$. Therefore, it is possible provide school meals by complying with the legal obligation of using $30 \%$ of the financial resources provided by FNDE for the purchase of family farm products ${ }^{17}$. Family farming represents a way of producing that is characterized by the interaction between management and labor. Family farmers carry out the process of production, emphasizing diversification and resorting to family labor, which, eventually, is supplemented by that of waged laborers ${ }^{38}$. Therefore, it is possible to observe the confluence of the objectives of the Programa de Aquisição de Alimentos (Food Acquisition Program) ${ }^{21}$ and those of PNAE. According to Belik \& Domene ${ }^{39}$, both programs' targets are to promote economic development, fight inequality, and assure food security.

According to a report by the World Food Program of 2013, Brazil stands out due to its link between the provision of school meals, food production, and community participation. The report also highlighted the Programa Nacional de Fortalecimento da Agricultura Familiar (Pronaf, National Program for Strengthening Family Farms), which is considered to be a Brazilian mainstay in the fight against famine and poverty, as it 
promotes the direct acquisition of food products from small landholders ${ }^{40}$.

According to Aguiar ${ }^{41}$, food produced for domestic consumption - that is approximately $70 \%$ of the food consumed daily - comes from family farms. Nevertheless, as Teo \& Monteiro ${ }^{13}$ pointed out, its relationship with the provision of school meals has offered a new opportunity to strengthen family farms, though legislation does not suffice to ensure that this closer relationship should translate necessarily into healthier school meals.

Barone ${ }^{14}$ stated that the introduction of family farming into the provision of school meals presents difficulties with regard to the management of PNAE. Therefore, it would be desirable for the federal government to provide training to technical staff, according to the requirements of different Brazilian regions. Furthermore, the difficulties in managing the program could be connected to the education of dieticians, since it would be necessary to include topics on public policy making in the curricula of nutrition courses. There are also negative aspects in the management of the program, which are connected to a lack of motivation on the part of technical responsibility when dealing with family farming. Therefore, it is necessary to evaluate other actors involved in the relationship between family farming and PNAE, such as the public managers and family farmers. Nevertheless, the link of family farming with PNAE has brought advantages to the municipalities and mainly to school children, thanks to the wider availability of local fruits and vegetables served at school meals.

In the last few years the debate about the importance of family farming for Brazil's development has gained momentum, inspired by sustainable development, food security, local development, job creation, and income gains. According to Figure 2, between 2002 and 2013 the resources transferred to Pronaf increased by $65 \%$, totaling 18 billion Brazilian reais (about US\$ 9 billion) in $2013^{38}$.

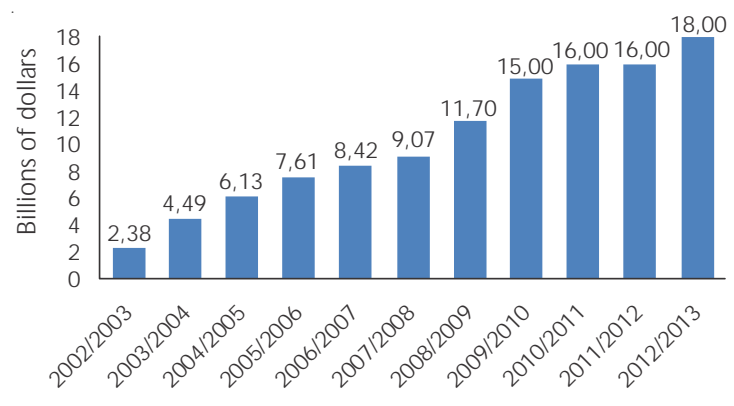

Figure 2. Resources destined for Programa Nacional de Fortalecimento da Agricultura Familiar between 2002 and 2013.

Source: Brasili|38.

\section{Centros Colaboradores em Alimentação e Nutrição do Escolar}

Another important social actor is the Centros Colaboradores em Alimentação e Nutrição Escolar (Cecane, Collaborating Centers for Students' Food and Nutrition), created to promote healthy eating in schools and composed of technicians and researchers in universities. The establishment of partnerships between public universities and FNDE has evidenced the commitment of the government and universities to support the Food Security and Nutrition Policy in Brazilian schools ${ }^{42}$.

The Centros Colaboradores em Alimentação e Nutrição Escolar actions were initially defined by the cooperation between the Ministry of Health and the Ministry of Education ${ }^{43}$ with the proposal of providing technical and operational support to states and municipalities, and since 2009 a federal resolution ${ }^{39}$ proposes the promotion of these actions.

Centers were formed in several Brazilian regions, and in the Southeast for example, it aims to undertake research activities, and teaching and extension in public schools; to promote healthy eating in schools of the region; and to provide continuing education to school meals'staff - dieticians and cooks ${ }^{42}$. In Southern Brazil, in order to train PNAE's management and social control, Cecane is conducting research to gain understanding of the 
nutritional and dietary characteristics of the population served by PNAE, especially those attending kindergarten in the states of Rio Grande do Sul and Santa Catarina. Other actions include training, technical support, and advice ${ }^{44}$.

Financial support and costs make up the basis of the material structure in the analysis of public policies. In PNAE, this structure is represented by the financing of the program by all three governmental spheres: federal, state, and municipal.

Financial resources provided by the federal government are prescribed by FNDE. States can transfer to their municipalities the responsibility for serving the students enrolled in state establishments within their area of jurisdiction. In this case, states may authorize the transfer of resources related to such students from FNDE directly to municipalities. Municipalities are not forced to provide school meals to students in the state network, and only through an agreement between both parties, can the service to such students be delegated from the state network to the municipalities ${ }^{45}$.

The necessary infrastructure for the program to work, both at a central level and in each school, also forms part of this material structure. The elements that form the basic infrastructure required for the effective performance of PNAE at schools are: the physical structure of kitchens, pantry, and cafeteria; kitchen equipment and utensils; personnel available to execute tasks; all in addition to the school staff and administrative personnel. In spite of the recent advances it is quite common to notice difficulties faced by municipalities when it comes to logistical and technical questions, as well as the insertion of nutrition education into the teaching project of a school ${ }^{14,32}$.

Financial resources necessary to operate the program for the provision of school meals are planned at the federal level and passed on to the state and municipal education secretaries to be topped up, as required. At present $R \$ 0.30$ (about US\$0.15) are passed on by the Union to the executive agencies destined for students enrolled in primary and secondary schools, and in Educação de Jovens e Adultos; R $\$ 0.50$ (US\$0.24) for students enrolled in preschools, except for those enrolled in schools in indigenous areas and areas deriving from quilombos; $\mathrm{R} \$ 0.60$ (US\$0.29) for students enrolled in schools of primary education in indigenous areas and areas deriving from quilombos; R\$1.00 (US\$0.49) for students enrolled in full-time education, with a minimum day of seven hours of schooling or school activities, according to the school census of the Ministry of Education; $R \$ 1.00$ (US\$0.49) for students enrolled in nurseries, including those located in indigenous areas and in areas deriving from quilombos, taking into account ethnic diversity and nutritional needs ${ }^{23}$. For the students of the Programa Mais Educação, which takes into account the implementation of full-time education in schools located in metropolitan areas with a high incidence of social vulnerability as one of its highest priorities, there is a financial complementation, so as to raise the per capita value to $\mathrm{R} \$ 0.90$ (US\$0.44), and for students who attend school in the opposite turn to their schedule of classes in the Atendimento Educacional Especializado the per capita value is $R \$ 0.50$ (US\$0.24). For the modality of part-time schooling known as Educação de Jovens e Adultos $20 \%$ are passed on from the resources ${ }^{20}$. These values, multiplied by the number of students from public schools in each Brazilian municipality add to 3.5 billion reais (US\$1.75 billion) destined for the execution of PNAE in $2013^{15}$. Out of the resources passed on by FNDE to executive agencies, at least $30 \%$ must be used for the acquisition of food products produced by family farms and rural family entrepreneurs.

Table 1 shows the values passed on after the decentralization of PNAE, from 1994 until now:

The financing of this program is the responsibility of the three spheres of government. 
Table 1. Per capita values (US\$) ${ }^{*}$ invested by the Brazilian federal government between 1994 and 2013 to the states and municipalities for school food.

\begin{tabular}{|c|c|c|c|c|c|c|c|c|}
\hline Modalities & $1994-2002$ & 2003 & 2004 & 2005 & $2006-2008$ & 2009 & 2010 & $2012-2013^{*}$ \\
\hline Nursery & - & 0.06 & 0.06 & 0.07 & 0.11 & 0.22 & 0.34 & 0.49 \\
\hline Kindergarten & 0.02 & 0.04 & 0.05 & 0.07 & 0.11 & 0.11 & 0.17 & 0.24 \\
\hline Elementary school & 0.04 & 0.04 & 0.05 & 0.07 & 0.11 & 0.11 & 0.17 & 0.15 \\
\hline High school & - & - & - & - & - & 0.11 & 0.17 & 0.15 \\
\hline Educação de jovens e adultos & - & - & - & - & - & 0.11 & 0.17 & 0.15 \\
\hline Indigenous schools & - & 0.11 & 0.12 & 0.14 & 0.22 & 0.22 & 0.34 & 0.29 \\
\hline Quilombola schools & - & 0.04 & - & 0.14 & 0.22 & 0.22 & 0.34 & 0.29 \\
\hline Programa Mais Educação & - & 0.04 & - & - & - & 0.33 & 0.51 & 0.44 \\
\hline
\end{tabular}

Note: *Average value of the dollar in 2012/2013.

Sources: Fundo Nacional de Desenvolvimento da Educação ${ }^{23}$ and Associação Comercial de São Paulo ${ }^{46}$

Federal and state financial resources can only be used for the acquisition of food products, and it is the responsibility of municipalities to fund further investments, such as the payment of wages to administrative teams at the central level, cooks, cooking gas, transportation of foodstuffs to the schools and additional sums for the acquisition of foodstuffs. Such expenditures must be included in the annual budget ${ }^{23}$.

States and municipalities that cannot provide enough financial resources for the program to work compromise the quality and amount of food products offered to their students.

The Programa Nacional de Alimentação Escolar (National School Food Program), as a policy associated with Brazilian public education, went through a great shift in paradigm since the advent of the new Federal Constitution in 1988. Until then, the provision of school meals was a handout in its character and involved the transfer of financial resources. Nevertheless, with the new constitution, it became a program to fulfill the right of students to appropriate meals on the one hand, and on the other, a duty of the State, whose responsibility to enforce it is shared by three federal entities, that is, the federal, state, and municipal governments ${ }^{19}$.

The field of provision of school meals is guided by values and knowledge developed in the practice of over half a century of interventions in the area. In other words, there is a collection - inherited from the twentieth century - of intervention tools and knowledge that play a counterpoint in such a complex area. Furthermore, when taking into account the specificity of school meals in Brazil, there are specific discourses which represent spheres of communication that establish links between the different actors involved ${ }^{10}$.

In Brazil, in the beginning of the twentieth century, medical knowledge took food into account only insofar as, through deterioration, there was a possibility that food products might infect people and places ${ }^{23}$. Therefore, food played no role in determining the health status of a population, be that of infants or of school-aged children. By that time this subject was exclusive of pediatricians, who touched upon it sporadically and superficially. It was only relevant when talking about boarding schools and houses, where food was offered to boarders. Such institutions prompted some attempts at standardization and supervision of services.

Between 1930 and 1964 Brazil went through a phase of so-called populism, characterized by government actions marked by the political manipulation of the lower classes, cronyism, and handouts ${ }^{47}$. Nevertheless, it was during this populist period that policies centered on food provision were necessary and thus reflected by various social programs.

With the beginnings of compulsory education in 1934, the municipality of Rio de Janeiro (1938) 
and the State of São Paulo (1945) gradually started to take on responsibility over the provision of school meals, influenced by the ideological and theoretical militancy of a group of professionals working in the new schools of public health and nutrition ${ }^{14}$. Policies to eradicate famine during the populist period were influenced by the ideas of Josué de Castro, who guided and inspired the drawing up of a public agenda of food and nutrition security in Brazil, which would come into its own in the following decades ${ }^{4}$.

Although Brazil was essentially an agrarian country at the time, a considerable part of the population suffered from famine and malnutrition due to archaic political and social structures. Policies set up by the Estado Novo (1937-1945) were openly populist and centered on the political manipulation of the lower social classes. Indeed, populism finds its roots in the formation of Brazilian society in the context of policies that supported industrialization and urbanization, which are still present nowadays. It was centered on actions and programs which were carried out in Brazil for a long time in order to offer welfare to disadvantaged people with a view to making them dependent and politically easy to control ${ }^{47}$. Therefore, food policies in Brazil, including the provision of school meals in public schools, had a handout character, even though their principles were scientific and broadly geared towards social justice ${ }^{48}$.

The prevailing ideology during the military years connected malnutrition to eating habits, which disagreed with humans' biological needs. Therefore, developing countries such as Brazil should give preference to processed, enriched foods. This philosophy contributed towards the rapid growth of the local food industry, especially of multinational food companies, since formulated food products offered certain operational advantages that optimized profit: reliable supply, low perishability, and ease of transportation, storage, and preparation ${ }^{4}$. On the other hand, the presence of formulated food products in school meals disregarded eating habits and, consequently, reduced their acceptance by school children.

The use of healthy and appropriate food products; the inclusion of food and nutrition education in the learning process; the regimen of cooperation between government sectors; support to sustainable development; and the acquisition of local food products only became directives of the provision of school meals again from 2003, with the program Fome Zero ${ }^{49}$.

In 2009 the Fundo Nacional de Desenvolvimento da Educação (National Education Development Fund) set out that the provision of school meals must guarantee at least $20 \%$ of the daily nutritional requirements of enrolled students and $30 \%$ in the case of indigenous students and quilombolas (socially vulnerable communities), with a view to meeting the nutritional needs of students during the school day, thus contributing to their growth, development, learning, and academic attainment. The compulsory use of $30 \%$ of the federal financial resources for the purchase of food produced by family farms aims to establish healthy eating habits, local economic growth, and regard for regional habits and for the agricultural inclination of a region ${ }^{45}$.

At present, use of the term "merenda escolar" or school snack should be discontinued, as this term is more akin to snacking. It should be replaced by school food, which offers a complete meal to students enrolled in public schools ${ }^{50}$.

\section{CONCLUSION}

In Brazil the supply of school meals arose as a handout policy at a time when famine and consequently, malnutrition were some of the country's most severe public health problems. Rather than a natural occurrence, famine has its roots in Brazil's socio-political structure, which has undergone many changes over the past sixty years. For decades, meals served at Brazilian state schools aimed both at correcting nutritional deficiencies and ensuring that socially vulnerable 
school children consumed a daily meal in some Brazilian regions. Indeed, extreme poverty is still rife and many students attend school in order to have access to school meals.

The urbanization and industrialization processes through which the country went through in the 1950s and during the years of the military regime (1964-1985) had a significant impact on school food. At first, the program introduced imported processed foods to strengthen commerce and later, it became characterized by the massive presence of the local processed food industry. Both the centralization of PNAE by the federal government and the development policy of the Brazilian agro-industrial sector were responsible for the 'industrialization' of school lunches. This terminology persists to this day and has been responsible for the notion of low quality foodstuffs which not only disregard the eating habits of schoolchildren, but also try to fulfil the role of providing a nutritious meal, regardless of its acceptability. During those years, the program of school meals in Brazil was a clear reflection of the workings of an authoritarian state.

With the process of re-democratization of the 1980s, the Brazilian State re-defined its educational policy, making it closer to a social agenda whose demands vied for the improvement of the country's educational system as a whole. Therefore, PNAE goes through a decentralization process; that is, the sharing of responsibility for the supply of school meals by the federal government, states, and municipalities. The management of the program became more efficient through the administration, processes, and, above all, the purchase of food products and the creation of school menus. Consequently, there begins a new cycle which aims at the sustainability of Brazilian school meals.

From 2003 the supply of school meals in Brazil became associated with a state policy of great coverage, the so-called Fome Zero, whose main goal was to guarantee access of all Brazilians to adequate food of good quality required for good health and wellbeing. Fome Zero was a sophisticated program insofar as it required the articulation of public policies geared towards education, health, agriculture, culture, and welfare. Such policies highlighted the socio-economic importance of family farming, making it compulsory that food products originating from family farming must be used for the creation of school meals. Although handout is still the preferred approach of many civil managers, it has been replaced by the promotion of health, improvement of the local economy, social inclusion and sustainable development.

In the past two decades there has been a $560 \%$ readjustment in federal resources to PNAE, added to complementary financial resources from states and municipalities. This readjustment has allowed for the setting up of a material structure for the implementation of this public policy. Nevertheless, it is important to point out that in a large country such as Brazil, which presents deep social and economic regional variations, the management of the program has not been uniform between municipalities and federal government.

Another important contribution of PNAE was the inclusion of food and nutrition education in the school curriculum, in the context of food security, as well as the human right to adequate and healthy food. Like other countries, Brazil faces now the challenge of fighting obesity and other chronic illnesses associated with poor eating habits, in addition to guaranteeing population access to produce.

Social control, exercised through the School Food Council, has the important role of supervising public investment in the supply of school meals and must act in partnership with the federal government to achieve the program's targets. At the same time, it remains important that the municipalities should invest in the training of counsellors, so that they are qualified to work within the program.

Finally, the evaluation of the management of PNAE in 5,570 Brazilian municipalities is still in its beginnings and based on the use of federal 
resources transferred to executive entities (states and municipalities), not taking into account the difficulties that managers have in administrating the program. Therefore, further studies and evaluations of the management of PNAE at a municipal level are required, since it is within the cities that PNAE caters for the population. Brazil has requested to cooperate internationally for the development of School Meal Programs in Latin America and the Caribbean, Portuguese Africa, Haiti, East Timor and Palestine, in partnership with the Food and Agriculture Organization of the United Nations and World Food Program. The success of PNAE remains an example to the world.

\section{CONTRIBUTORS}

RM NOGUEIRA and B BARONE, analyzed and interpreted the data and wrote the article. TT BARROS analyzed and interpreted the data and wrote the article. KRLSLQ GUIMARÃES analyzed the data, and drafted and wrote the article. NSS RODRIGUES drafted the article. JH BEHRENS supervised the study and outlined the article.

\section{REFERENCES}

1. Magno MSO, Cyrillo DC, Sarti, FM. Evolução da alimentação escolar no município de São Paulo-SP. Nutrire Soc Bras Aliment Nutr. 2013; 38(1):83-96. http://dx.doi.org/10.4322/nutrire.2013.009

2. Food and Nutrition Service. National School Lunch Program. Background and Development. Alexandria (VA): Food and Nutrition Service; 2013 [cited 2015 Feb 25]. Available from: http://www. fns.usda.gov/sites/default/files/NSLP-Program\% 20History.pdf

3. Ceccim RB. A merenda escolar na virada do século, agenciamento pedagógico da cidadania. Em Aberto. 1995 [acesso 2015 out 7]; 15(67):1-158. Disponível em: http://emaberto.inep.gov.br/index.php/ emaberto/article/viewFile/1006/909

4. Coimbra M, Meira JFP, Starling MBL. Comer e aprender: uma história da alimentação escolar no Brasil. Belo Horizonte: Inae; 1982.

5. Brasil. Câmara dos Deputados. Decreto n 37.106, de 31 de março de 1955. Institui a companhia da Merenda Escolar. Diário oficial da União. 19952 abr; Seção 1 [acesso 2015 out 6]. Disponível em: http://www2.camara.leg.br/legin/fed/decret/19501959/decreto-37106-31-marco-1955-332702publicacaooriginal-1-pe.html

6. Nogueira RM. O Programa Nacional de Alimentação Escolar como uma política pública: o caso de Campinas - SP [mestrado]. Campinas: Unicamp; 2005.

7. Paiva JB, Freitas MCS, Santos LAS. Hábitos alimentares regionais no Programa Nacional de Alimentação Escolar: um estudo qualitativo em um município do sertão da Bahia, Brasil. Rev Nutr. 2012; 25(2):191-202. http://dx.doi.org/10.1590/\$1415-52 732012000200002

8. Brasil. Senado Federal. Secretaria de Informação Legislativa. Decreto $n^{\circ} 72.034$, de 30 de março de 1973. Institui o Programa Nacional de Alimentação e Nutrição (Pronan), aprova o I Pronan e dá outras providências. Diário Oficial da União. $19733 \mathrm{abr}$ [acesso 2015 out 6]. Disponível em: http://legis. senado.gov.br/legislacao/ListaTextolntegral. action?id=185921\&norma=201668

9. Brasil. Senado Federal. Secretaria de Informação Legislativa. Decreto $n^{\circ} 77.116$, de 6 fevereiro de 1976. Estabelece diretrizes para a ação do governo na área de Alimentação e Nutrição, aprova o Programa Nacional de Alimentação e Nutrição (Pronan) e da outras providências. Diário Oficial da União. 19766 fev [acesso 2015 out 6]. Disponível em: http://legis.senado.gov.br/legislacao/Lista Publicacoes. action? $\mathrm{id}=123256$

10. Di Giovanni G. As estruturas elementares das políticas públicas. Caderno de Pesquisa $n^{\circ} 82$. Campinas: Núcleo de Estudos de Politicas Públicas; 2009 [acesso 2015 out 6]. Disponível em: https:// observatorio03. files.wordpress.com/2010/06/ elementos-das-politicas-publicas.pdf

11. Organização das Nações Unidas. Com 47 milhões de crianças alcançadas, Brasil é referência global em refeições escolares. Brasília: ONU; 2013 [acesso 2013 ago 20]. Disponível em: http://www.onu. org.br/com-47-milhoes-de-criancas-alcancadasbrasil-e-referencia-global-em-refeicoes-escolares

12. Carvalho DGO. Programa Nacional de Alimentação Escolar e a sustentabilidade: o caso do Distrito Federal (2005-2008) [mestrado]. Brasília: UnB; 2009.

13 Teo CRPA, Monteiro CA. Marco legal do Programa Nacional de Alimentação Escolar: uma releitura para alinhar propósitos e práticas na aquisição de alimentos. Rev Nutr. 2012; 25(5):657-68. http:// dx.doi.org/10.1590/S1415-52732012000500010

14. Barone B. Participação da agricultura familiar na alimentação escolar na região administrativa de Registro-SP [mestrado]. Campinas: Unicamp; 2014.

15. Fundo Nacional de Desenvolvimento da Educação. Alimentação escolar. Brasília: FNDE; 2013 [acesso 2014 dez 26]. Disponível em: http://www.fnde.gov. 
br/programas/alimentacao-escolar/alimentacaoescolar-apresentacao

16. Villar BS, Schwartzman F, Januario BL, Ramos JF. Situação dos municípios do estado de São Paulo com relação à compra direta de produtos da agricultura familiar para o Programa Nacional de Alimentação Escolar (PNAE). Rev Bras Epidemiol. 2013; 16(1):223-6. http//:dx.doi.org/10.1590/S1 415-790X2013000100021

17. Brasil. Lei $n^{\circ} 11.947$, de 16 de junho de 2009. Dispõe sobre o atendimento da alimentação escolar e do Programa Dinheiro Direto na Escola aos alunos da educação básica. Diário Oficial da União. 2009 17 jun [acesso 2015 set 15]. Disponível em: http:// www.planalto.gov.br/ccivil_03/_ato2007-2010/ 2009/lei/111947.htm

18. Brasil. Presidência da República. Lei $n^{\circ} 12.982$, de 28 maio de 2014. Altera a Lei $n^{\circ} 11.947$, de 16 de junho de 2009, para determinar o provimento de alimentação escolar adequada aos alunos portadores de estado ou de condição de saúde específica. Diário Oficial da União. 201429 maio [acesso 2015 set 15]. Disponível em: http://www. planalto.gov.br/ ccivil_03/_Ato2011-2014/2014/Lei/L12982.htm

19. Peixinho AML. A trajetória do Programa Nacional de Alimentação Escolar no período de 2003-2010: relato do gestor nacional. Ciênc Saúde Colet. 2013; 18(4):909-16. http://dx.doi.org/10.1590/S1413-8 1232013000400002

20. Brasil. Presidência da República. Lei n 11.326, de 24 de julho de 2006. Estabelece as diretrizes para a formulação da Política Nacional da Agricultura Familiar e Empreendimentos Familiares Rurais. Diário Oficial da União. 200625 jul [acesso 2015 set 15]. Disponível em: http://www.planalto.gov.br/ ccivil_03/_ato2004-2006/2006/lei/l11326.htm

21. Brasil. Presidência da República. Lei n 10.696 de 2 de julho de 2003. Dispõe sobre repactuação e o alongamento de dívidas oriundas de operações de crédito rural, e dá outras providências. Diário Oficial da União. 20032 jul [acesso em 2015 set 18]. Disponível em: http://www.planalto.gov.br/ccivil_ 03/leis/2003/L10.696.htm

22. Câmara de Segurança Alimentar e Nutricional. Plano nacional de segurança alimentar e nutricional: 2012/2015. Brasília: Caisan; 2011 [acesso 2015 fev 27]. Disponível em: http://www.mds.gov.br/ segurancaalimentar/arquivos/LIVRO_PLANO_ NACIONAL_CAISAN_FINAL.pdf

23. Fundo Nacional de Desenvolvimento da Educação. Resolução n² 26, de 17 de junho de 2013. Dispõe sobre 0 atendimento da alimentação escolar aos alunos da educação básica no âmbito do Programa Nacional de Alimentação Escolar - PNAE. Diário
Oficial da União. 201318 jun [acesso 2015 set 15]. Disponível em: https://www.fnde.gov.br/fndelegis/ action/UrlPublicasAction.php

24. Chaves LG, Santana TCM, Gabriel CG, Vasconcelos FAG. Reflexões sobre a atuação do nutricionista no Programa Nacional de Alimentação Escolar no Brasil. Ciênc Saúde Colet. 2013; 18(4):917-26. http// :dx.doi.org/10.1590/S1413-81232013000400003

25. Saraiva EB, Silva APF, Sousa AA, Cerqueira GF, Chagas CMS, Toral N. Panorama da compra de alimentos da agricultura familiar para o programa nacional de alimentação escolar. Ciênc Saúde Colet. 2013; 18(4):927-36. http//:dx.doi.org/10.1590/S14 13-81232013000400004

26. Brasil. Presidência da República. Constituição da República Federativa do Brasil de 1988. Constituição da República Federativa do Brasil: promulgada em 5 de outubro de 1988. Brasília: Presidência da República; 1988.

27. Arretche MTS. Políticas Sociais no Brasil: descentralização em um Estado federativo. Rev Bras Ciên Soc. 1999; 14(40):111-41. http//:dx.doi.org/10. 1590/S0102-69091999000200009

28. Instituto Nacional de Estudos e Pesquisas Educacionais Anísio Teixeira. Avaliação da descentralização de recursos do FNDE e da merenda escolar: síntese dos resultados. Brasília: Inep; 1998 [acesso 2015 set 15]. Disponível em: http://www.dominio publico.gov.br/download/texto/me002213.pdf

29. Spinelli MAS, Canesqui AM. O programa de alimentação escolar no estado de Mato Grosso: da centralização à descentralização (1979-1995). Rev Nutr. 2002; 15(1):105-17. http//:dx.doi.org/10. 1590/S1415-52732002000100011

30. Brasil. Presidência da República. Medida Provisória $n^{\circ}$ 1.979-19, de 3 de junho de 2000. Dispõe sobre o repasse de recursos financeiros do Programa Nacional de Alimentação Escolar, institui o Programa Dinheiro Direto na Escola, e dá outras providências. Diário Oficial de União. 20002 jun [acesso 2015 set 18]. Disponível em: http://www. planalto.gov.br/ccivil_03/mpv/Antigas/1979-19. htm

31. Lüchmann LHH. Os conselhos gestores de políticas públicas: desafios do desenho institucional. Ciênc Sociais Unisinos. 2002; 38(161):43-79.

32. Barros TT. Atuação dos Conselhos Municipais de Alimentação Escolar (CAE) na Região Metropolitana de Campinas e na Região Administrativa de Registro, estado de São Paulo [mestrado]. Campinas: Unicamp; 2014.

33. Gabriel CG, Machadol MS, Schmitz BAS, ACT Corso, Caldeiras GV, Vasconcelos FAG. Conselhos 
municipais de alimentação escolar em Santa Catarina: caracterização e perfil de atuação. Ciênc Saúde Colet. 2013; 18(4):971-8. http//:dx.doi.org/10.15 90/S1413-81232013000400009

34. Pipitone MAP, Ometto AMH, Silva MV, Sturion GL, Furtuoso COM, Oetterer M. Atuação dos conselhos municipais de alimentação escolar na gestão do programa nacional de alimentação escolar. Rev Nutr. 2003; 16(2):143-54. http://dx.doi.org/10.15 90/S1415-52732003000200001

35. Santos LMP, Araújo MPN, Martins MC, Veloso IS, Assunção MP, Santos SMC. Avaliação de políticas públicas de segurança alimentar e combate à fome no período 1995-2002 - Programa Nacional de Alimentação Escolar. Cad Saúde Pública. 2007; 23(11):2681-93. http://dx.doi.org/10.1590/S0102-3 $11 \times 2007001100016$

36. Machado PMO, Schmitz BAS, Corso ACT, Caldeira GV, Vasconcelos FAG. Conselhos de alimentação escolar em Santa Catarina, Brasil: uma análise do discurso do sujeito coletivo. Rev Nutr. 2015; 28(3):305-17. http://dx.doi.org/10.1590/1415-527 32015000300007

37. Pereira CV, Medeiros PHR. O controle social e o Tribunal de Contas da União: o caso dos conselhos de alimentação escolar. Rev TCU. 2005; 35:42-54.

38. Brasil. Ministério do Desenvolvimento Social e Combate à Fome. Programa de Aquisição de Alimentos. Brasília: Ministério do Desenvolvimento Social e Combate à Fome; 2013 [acesso 2013 out 28]. Disponível em: http://www.mds.gov.br/ segurancaalimentar/decom/paa

39. Belik W, Domene SMA. Experiências de programas combinados de alimentação escolar e desenvolvimento local em São Paulo - Brasil. Rev Agroalim. 2012; 18(34):57-72.

40. World Food Programme. State of school feeding worldwide. Rome: World Food Programme; 2013 [cited 2014 Oct 18]. Available from: https://www. wfp.org/content/state-school-feeding-worldwide2013

41. Aguiar JA. Planejamento de ações para agricultura familiar. São Paulo: Conselho Estadual de Alimentação Escolar de São Paulo; 2012 [acesso 2012 maio 7]. Disponível em: http://issuu.com/ceaesp/docs/ agricultura_familiar.jeanice_aguiar
42. Gaglianone CP, Devincenzi MU, Batista SH, Castro PM, Stedefeldt E. Centro colaborador em alimentação e nutrição escolar - Cecane Unifesp: finalidade e projetos. Rev Assoc Bras Nutr. 2009; 2(1):58-62.

43. Fundo Nacional de Desenvolvimento da Educação. Portaria Interministerial $n^{\circ} 1010$ de 8 de maio de 2006. Institui as diretrizes para a Promoção da Alimentação Saudável nas Escolas de educação infantil, fundamental e nível médio das redes públicas e privadas, em âmbito nacional. Brasília: FNDE; 2006 [acesso 2015 set 15]. Disponível em: https://www.fnde.gov.br/fndelegis/action/Url PublicasAction.php

44. Scarparo ALS, Moulin CC, Ruiz EF, Schuch I, Araújo JS, Souza M, et al. Ações do centro colaborador em alimentação e nutrição do escolar da Universidade Federal do Rio Grande do Sul. Rev HCPA. 2010; 30(3):302-5.

45. Brasil. Resolução n 38, de 16 de julho de 2009. Dispõe sobre o atendimento da alimentação escolar aos alunos da educação básica no Programa Nacional de Alimentação Escolar - PNAE. Diário Oficial da União. 200917 de set.

46. Associação Comercial de São Paulo. Economia. São Paulo: Associação Comercial de São Paulo; 2013 [acesso 2013 jun 27]. Disponível em: http:// economia.acspservicos.com.br/IEGV/IEGV_DOLAR. HTM

47. Menezes F, Santarelli M. Da estratégia "Fome Zero" ao "Plano Brasil sem miséria": elementos da Seguridade Social no Brasil. Rio de Janeiro: Instituto Brasileiro de Análises Sociais e Econômicas; 2013.

48. Castro J. Geografia da fome, o dilema brasileiro: pão ou aço. $6^{a}$ ed. Rio de Janeiro: Civilização; 2006.

49. Brasil. Ministério do Desenvolvimento Social e Combate á Fome. Fome Zero. Brasília: Ministério do Desenvolvimento Social e Combate á Fome; 2013 [acesso 2013 ago 8]. Disponível em: http:// www.fomezero.gov.br

50. Weis B, Chaim N, Belik W. Manual de gestão eficiente da merenda escolar. $3^{a}$ ed. São Paulo: Ação Fome Zero; 2007 [acesso 2014 nov 28]. Disponível em: http://www.acaofomezero.org.br

Received: May 11, 2015

Final version: October 8, 2015 Approved: October 24, 2015 
